\title{
PENGETAHUAN DAN SIKAP WANITA RAWAN SOSIAL EKONOMI (WRSE) TENTANG PENCEGAHAN PENANGGULANGAN HIV/AIDS DI KOTA PEKALONGAN TAHUN 2014
}

\author{
Ida Baroroh, Nur Hidayati, Dian Kusumawardani
}

(Akademi Kebidanan Harapan Ibu Pekalongan)

\begin{abstract}
Human Immunodeficiency Virus (HIV) is the virus that causes Acquired Immunodeficiency Syndrome (AIDS), which is a global health problem in both developed and developing countries. HIV / AIDS is a sexually transmitted disease that can be transmitted throughout society from infants to adults both male and female. Women's socio-economic prone included into the vulnerable groups because of poor health status, durability and family welfare would have the potential to perform high-risk of HIV infection and AIDS. The purpose of the research is to analyze the knowledge and attitudes of women's socio-economic prone on the prevention of transmission of HIV / AIDS in Pekalongan.

This research method is quantitative and qualitative. The samples of this research are 47 WRSE in Pekalongan, taken 4 WRSE study subjects aged 18-50 years with criteria, are married and have children, widows live / dead widow who becomes the primary breadwinner families or married to a husband who worked at sea for long periods (return 3 months or more), working as a bus driver Inter-City Inter-Province (AKAP), truck drivers, or work outside the city without clarity, have dependents by more than 3 people, stay in Pekalongan. Collecting data through in-depth interviews and analysis with content-analysis.

The results showed WRSE knowledge about STDs, HIV / AIDS as well as an overview of HIV disease AIDS is still very limited, limited knowledge society is due to the lack of dissemination to the public of information relating to HIV / AIDS and VCT clinics presence in Pekalongan by the Government. Negative attitudes towards PLHIV community committed (People Living with HIV / AIDS) is caused by ignorance of the community clearly.

It is recommended to promote coordination among agencies in providing public education, socialization expanded, the type of information plus, especially socialization related to the prevention of disease transmission, forming an organization engaged in the protection and prevention of HIV/AIDS.
\end{abstract}

Keywords: HIV / AIDS, WRSE, Knowledge, Attitude Literature: $26(1999$ - 2013)

\section{PENDAHULUAN}

Kasus HIV/AIDS sejak pertama kali ditemukan yaitu pada tahun 1987 sampai Juni 2012 terdapat 30.103 kasus AIDS dan 86.762 terinfeksi HIV di 33 propinsi di Indonesia. Jumlah kasus AIDS terbanyak dilaporkan dari Papua (7.527 kasus), DKI Jakarta (6.299 kasus), Jawa Timur (5.257 kasus), Jawa Barat (4.098 kasus), Bali (2.939 kasus), Jawa Tengah (2.503 kasus), Kalimantan Barat (1.699 kasus), Sulawesi Selatan (1.377 kasus), Riau (775 kasus), dan Sumatera Barat (715 kasus). Angka kematian AIDS menurun dari 2,8\% pada tahun 2011 menjadi 1,6\% pada September 2012 (Depkes, 2012).
Presentase komulatif AIDS tertinggi pada umur 20-29 tahun (41,5\%), kemudian diikuti kelompok umur 30-39 tahun (30,8\%), 40-49 tahun (11,6\%), 15-19 tahun $(4,1 \%)$, dan 50-59 tahun $(3,7 \%)$. Rasio kasus AIDS antara laki-laki dan perempuan adalah 2:1 (laki - laki 70\% dan perempuan 29\%). Presentase faktor resiko AIDS tertinggi adalah hubungan seks tidak aman pada heteroseksual (84,5\%), pengguna jarum suntik tidak steril pada penasun (6\%), dari ibu positif HIV ke anak (3,9\%), lelaki seks lelaki (3,9\%) (Ditjen PP \& PL Kemenkes RI, 2012).

Kasus AIDS di Jawa Tengah, dari tahun 1993 sampai dengan 31 maret 2012 
jumlah kasus 4.922 orang dengan HIV: 2.769 kasus, AIDS: 2.153 orang dan meninggal 603 orang. proporsi jumlah AIDS sebanyak 38,3\% laki-laki, sebanyak $61,7 \%$ kelompok wanita. Dilihat dari kelompok penderita yang terbesar pada kelompok umur 25-29 tahun yaitu 574 $(26,66 \%)$ sebanyak, umur 30-34 tahun yaitu 447 (20,76\%), umur 35-39 tahun yaitu $331(15,37 \%)$ Sedangkan bila dilihat dari pekerjaan penderita ternyata yang paling banyak adalah wiraswasta yaitu 439 (39\%), ibu rumah tangga yaitu sebesar 394 $(18,3 \%)$ disusul kelompok karyawan sebesar 223(10,36\%). Ada sekitar 81 anak di bawah usia 15 tahun yang sudah menderita HIV/AIDS yang berasal dari ibunya (Profil Kesehatan Jawa Tengah Tahun 2012).

Jumlah penderita HIV/AIDS di Kota Pekalongan meningkat signifikan sepanjang tahun 2013 yaitu mencapai 23 orang. Sementara pada tahun sebelumnya, jumlah penderita HIV/AIDS hanya 13 orang. Peningkatan yang signifikan tersebut salah satunya dikarenakan faktor screening yang mengalami peningkatan. Penderita HIV/AIDS di Kota Pekalongan terdiri dari ibu rumah tangga, karyawan, buruh dan wiraswasta. Dua diantara jumlah penderita adalah anak-anak yang tertular dari ibunya.Sementara itu, dari jumlah penderita HIV/AIDS sebanyak 23 sepanjang tahun 2013, lima orang di antaranya meninggal. Jumlah ini turun dibandingkan tahun sebelumnya (Dinas Kesehatan Kota Pekalongan, 2013).

Berdasarkan data dari Dinas Sosial dan Ketenagakerjaan Kota Pekalongan didapatkan jumlah wanita rawan sosial ekonomi (WRSE) di Pekalongan pada tahun 2010 sebanyak 804 orang. Data terbaru tahun 2013 jumlah WRSE di Kota Pekalongan menurun menjadi 615 orang.

HIV/AIDS merupakan penyakit menular seksual yang dapat menular seluruh lapisan masyarakat dari mulai bayi sampai dewasa baik laki-laki maupun perempuan.Sedangkan kelompok resiko tertinggi terhadap infeksi HIV adalah homoseksual, pria biseksual, penyalahgunaan obat-obatan intravena, kaum prostitusi, dan mitra heteroseksual pria yang berada dalam kelompok resiko tinggi (Pernoll dan Ralph, 2005).

Adanya perilaku menyimpang masyarakat mulai dari pekerja seks komersial, homoseksual, dan pengguna jarum suntik yang saling bergantian sangat mempengaruhi meningkatnya penyebaran HIV/AIDS di Indonesia. Adanya pola transmisi yang berkembang selain hanya transmisi seksual, juga menular melalui transmisi plasental (dari ibu ke janinnya) menjadi ancaman baru yang melahirkan korban yang tidak berdosa. Pola pemberantasan HIV/AIDS di Indonesia harus dilakukan secara nasional melalui kebijakan khusus pemerintah dan diharapkan hal itu mampu menyelamatkan SDM (sumber daya manusia) usia produktif yang berpotensi bagi pembangunan dari penyebaran HIV/AIDS di lingkungan masyarakat (Adisasmito, 2012).

Virus HIV/AIDS adalah penyakit menular melalui hubungan seksual. Oleh karena itu, wanita rawan sosial ekonomi rentan terjangkit penyakit ini karena mereka mempunyai kemungkinan yang besar untuk menjadi pekerja seks komersial yang disebabkan desakan ekonomi maupun berhubungan intim dengan suami yang bekerja diluar kota dalam waktu lama dan terbiasa melakukan hubungan seks berisiko selain dengan pasangan tetap (istri) namun tidak mau terbuka kepada keluarga bila terinfeksi virus HIV. Wanita rawan sosial ekonomi termasuk kedalam kelompok rentan karena rendahnya status kesehatan, daya tahan dan kesejahteraan keluarga akan berpotensi melakukan perilaku beresiko terinfeksi 
HIV dan AIDS (Perda Kabupaten Batang No 3 Tahun 2011).

Kajian sosiologi feminis menjelaskan ibu rumah tangga rentan terinfeksi virus HIV/AIDS karena rendahnya daya tawar dan negosiasi dalam hal berhubungan seksual. Kenyataan ini sesuai dengan laporan Badan AIDS PBB atau UNAIDS, yang menyebutkan lebih dari 1,7 juta perempuan di ASIA hidup dengan HIV positif, dan 90\%-nya tertular dari suami atau pasangan seksual.

Suatu perilaku yang tepat dapat menghindari bahaya HIV/AIDS harus dimulai dari pengetahuan yang memadai mengenai HIV/AIDS itu sendiri. Di samping untuk mencegah diri dari melakukan berbagai hal yang beresiko menularkan HIV/AIDS, juga membantu kita untuk dapat berperilaku yang tepat kepada penderita HIV/AIDS. Sebuah penelitian yang dilakukan oleh Davis, Sloan, MacMaster, dan Kilbourne (2007) dalam Vella (2011), yang meneliti kaitan antara pengetahuan dan aktifitas seksual yang dilakukan oleh kelompok mahasiswa mengungkap pentingnya kesadaran (pengetahuan) akan HIV/AIDS. Penelitian tersebut menemukan bahwa niat untuk menggunakan kondom pada mahasiswa yang hendak melakukan one-night stand memiliki kaitan yang kuat dengan kesadaran terhadap HIV/AIDS. Suatu niat untuk menggunakan kondom di masa mendatang juga memiliki korelasi yang signifikan dengan peningkatan efikasi diri untuk menggunakan kondom serta sikap positif terhadap hubungan seks yang aman.

Pengkajian pengetahuan, sikap wanita rawan sosial ekonomi merupakan suatu upaya pencegahan penularan HIV/AIDS. Upaya pencegahan penularan HIV/AIDS diharapkan dapat mengurangi penularan HIV/AIDS dalam satu keluarga, virus HIV dari suami ke ibu rumah tangga dan dilanjutkan penularan ke anak saat persalinan.
Berdasarkan latar belakang di atas, maka pertanyaan penelitian sebagai berikut: "Bagaimana pengetahuan dan sikap Wanita Rawan Sosial Ekonomi (WRSE) terhadap pencegahan penularan HIV/AIDS di Kota Pekalongan?”.

\section{METODE PENELITIAN}

Penelitian ini menggunakan kombinasi metode kuantitatif dan kualitatif, dimana variabel kuantitatif terdiri dari variabel pengetahuan dan sikap dengan metode pengumpulan data menggunakan kuesioner. Pengkajian pengetahuan dan sikap digunakan untuk mendapatkan informan utama dalam penelitian kualitatif. Jenis penelitian selanjutnya adalah metode kualitatif yang disajikan secara deskriptif melalui wawancara mendalam dengan pedoman wawancara untuk mendapatkan pemahaman tentang pengetahuan dan sikap Wanita Rawan Sosial Ekonomi (WRSE) sebagai ibu rumah tangga dalam upaya pencegahan penularan HIV/AIDS kepada keluarga maupun orang lain yang belum tertular dan terjangkit HIV/AIDS

Untuk mendapatkan informan sesuai dengan tujuan penelitian yaitu informan yang dapat memberikan informasi tentang pencegahan penularan HIV/AIDS terhadap Wanita Rawan Sosial Ekonomi (WRSE). Ditentukan subyek penelitian sebagai informan utama adalah ibu rumah tangga yang masuk dalam kriteria wanita rawan sosial ekonomi (WRSE). Pengumpulan data primer dilakukan dengan memberikan kuesioner kepada 1 orang Wanita Rawan Sosial Ekonomi (WRSE) disetiap kelurahan di wilayah Kota Pekalongan yang berisi pengkajian pengetahuan dan sikap terhadap pencegahan penularan HIV/AIDS dan diolah menggunakan analisis univariat pada masing-masing variabel. Hasil analisis univariat dengan perbedaan nilai pengetahuan dan sikap yang signifikan 
kemudian dipilih 6 orang untuk menjadi informan utama. Enam orang informan utama kemudian dilakukan wawancara mendalam (Indepth Interview) sebagai metode pengumpulan data kualitatif. Wawancara mendalam dilakukan kepada Wanita Rawan Sosial Ekonomi (WRSE) sebagai ibu rumah tangga yang memenuhi kriteria yaitu : umur 18-50 tahun, sudah menikah dan mempunyai anak, janda hidup/mati yang menjadi pencari nafkah utama keluarga atau menikah dengan suami yang bekerja di laut dalam waktu lama (pulang 3 bulan sekali atau lebih), bekerja sebagai supir bus Antar Kota Antar Propinsi (AKAP), supir truk, atau bekerja diluar kota tanpa kejelasan, memiliki tanggungan keluarga sebanyak lebih dari 3 orang dan berdomisili di wilayah kota Pekalongan.

Adapun Informan Triangulasi dalam penelitian ini adalah Kepala Bidang P2 dan PL Dinas Kesehatan Kota Pekalongan, Kepala Bidang Sosial Dinas Sosial Kota Pekalongan, Kepala Seksi Pendayaan Perempuan dan Perlindungan Anak BPMP2AKB Kota Pekalongan dan Case Manager Klinik VCT BKPM Kota Pekalongan.

Metode pengumpulan data dalam penelitian ini dibagi menjadi 2 macam, yaitu data primer dan data sekunder. Data primer dalam penelitian ini yaitu wawancara mendalam. Wawancara mendalam digunakan untuk mendapatkan data primer. Wawancara mendalam dengan informan utama dan triangulasi tentang pencegahan penularan HIV/AIDS terhadap Wanita Rawan Sosial Ekonomi (WRSE). Tujuan wawancara mendalam dalam penelitian ini adalah untuk memperoleh informasi yang dapat dipercaya atau memperoleh pendapat yang didasarkan informasi yang obyektif dan cermat tentang pencegahan penularan HIV/AIDS terhadap Wanita Rawan Sosial Ekonomi (WRSE). Sedangkan data sekunder dalam penelitian ini adalah data jumlah WRSE dari Dinas Sosial Kota Pekalongan dan Jumlah ODHA di wilayah Kota Pekalongan dari Dinas Kesehatan Kota Pekalongan.

Instrumen Pengumpulan data yang digunakan yaitu instrumen pengumpulan data kuantitatif dan kualitatif. Adapun instrumen pengumpulan data kuantitatif dengan menggunakan kuesioner. Kuesioner diberikan kepada ibu rumah tangga yang termasuk dalam kriteria inklusi (Wanita Rawan Sosial Ekonomi/WRSE). Sedangkan instrumen penelitian kualitatif adalah peneliti. Pengumpulan data dilakukan dengan wawancara mendalam (indepth interview), untuk mengumpulkan data didapatkan dari : Pedoman wawancara mendalam, yang berisi pertanyaan terbuka tentang pengetahuan dan sikap dalam pencegahan penularan HIV AIDS dan Tape recorder untuk merekap hasil wawancara, alat tulis (buku dan bolpoint) untuk mencatat informasi yang diperoleh.

\section{HASIL DAN PEMBAHASAN}

\section{a. Data Kuantitatif}

Dari 47 responden, sebanyak 31 responden berpengetahuan kurang, 15 responden berpengetahuan cukup dan hanya 1 orang berpengetahuan baik tentang pencegahan penularan HIV AIDS. Dan data sikap diperoleh sebanyak 25 responden mempunyai sikap negatif dan 22 responden lainnya mempunyai sikap positif tentang pencegahan penularan HIV AIDS.

Dari Hasil penilaian pengetahuan dan sikap diambil 8 informan utama dengan nilai hasil pengetahuan kurang dan sikap negatif atau pengetahuan cukup dengan sikap negatif. 


\section{b. Data Kualitatif}

1. Karakteristik Informan Utama

Tabel 3.1.1 Karakteristik Informan Utama

\begin{tabular}{|l|l|c|c|c|c|c|c|}
\hline No. & $\begin{array}{c}\text { Kode } \\
\text { Informan }\end{array}$ & $\begin{array}{c}\text { Usia } \\
\text { (Thn) }\end{array}$ & $\begin{array}{c}\text { Pendidik } \\
\text { an }\end{array}$ & $\begin{array}{c}\text { Pekerj } \\
\text { aan }\end{array}$ & Status & $\begin{array}{c}\text { Tanggun } \\
\text { gan } \\
\text { Keluarga }\end{array}$ & $\begin{array}{c}\text { Pekerjaa } \\
\text { n Suami }\end{array}$ \\
\hline 1. & IU.1U & 50 & $\begin{array}{c}\text { Tidak } \\
\text { sekolah }\end{array}$ & $\begin{array}{c}\text { Buruh } \\
\text { Batik }\end{array}$ & Menikah & 7 orang & $\begin{array}{c}\text { Supir Bis } \\
\text { AKAP }\end{array}$ \\
\hline 2. & IU.2T & 50 & $\begin{array}{c}\text { Tidak } \\
\text { sekolah }\end{array}$ & $\begin{array}{c}\text { Dagan } \\
\text { g }\end{array}$ & Menikah & 4 orang & supir truk \\
\hline 3. & IU.3B & 32 & SMA & $\begin{array}{c}\text { Dagan } \\
\text { g }\end{array}$ & $\begin{array}{c}\text { Janda } \\
\text { Mati }\end{array}$ & 4 orang & - \\
\hline 4. & IU.4S & 50 & $\begin{array}{c}\text { Tidak } \\
\text { sekolah }\end{array}$ & $\begin{array}{c}\text { Dagan } \\
\text { g }\end{array}$ & Menikah & 7 orang & Supir truk \\
\hline 5. & IU.5T & 21 & SMP & $\begin{array}{c}\text { IRT } \\
\text { Menikah }\end{array}$ & 3 orang & $\begin{array}{c}\text { Buruh } \\
\text { luar kota }\end{array}$ \\
\hline 6. & IU.6B & 40 & SD & Buruh & Janda & 3 orang & - \\
\hline 7. & IU.7S & 24 & SMP & $\begin{array}{c}\text { IRT } \\
\text { Menikah }\end{array}$ & 3 orang & $\begin{array}{c}\text { Buruh } \\
\text { luar kota }\end{array}$ \\
\hline 8. & IU.8U & 34 & SMP & $\begin{array}{c}\text { Buruh } \\
\text { batik }\end{array}$ & Menikah & 6 orang & Supir truk \\
\hline
\end{tabular}

Berdasarkan tabel diatas diketahui bahwa informan utama sejumlah 8 orang dengan karakteristik umur antara 21-50 tahun, dan riwayat pendidikan terakhir tidak bersekolah - tamatan SMA. Adapun status informan utama adalah 6 orang menikah (suami masih hidup), 1 orang adalah janda mati dan 1 orang janda cerai hidup. Jumlah anggota keluarga yang menjadi tanggungan 2 informan utama adalah 7 orang, 1 informan utama memiliki 6 orang tanggungan keluarga, 2 orang informan utama memiliki tanggungan keluarga sebanyak 4 orang dan 3 informan utama yang lain memiliki tanggungan keluarga sebanyak 3 orang. Pekerjaan ratarata suami informan utama adalah 3 orang supir truk, 1 orang supir bis AKAP dan 2 orang buruh luar kota.

2. Karakteristik Informan Triangulasi

Tabel 4.1.2 Karakteristik Informan Triangulasi

\begin{tabular}{|l|l|l|l|l|l|}
\hline No & KodeInforman & $\begin{array}{c}\text { Usia } \\
\text { (Tahun) }\end{array}$ & Pendidikan & $\begin{array}{l}\text { Pekerjaan / } \\
\text { Jabatan }\end{array}$ & \multicolumn{1}{|c|}{$\begin{array}{c}\text { Lama } \\
\text { Bekerja }\end{array}$} \\
\hline 1. & IT.1 & 42 tahun & S2 & PP dan PA & 3 tahun \\
\hline 2. & IT.2 & 53 tahun & S1 & PP dan PL & 3 tahun \\
\hline 3. & IT.3 & 54 tahun & S2 & Kabid sosial & 1,5 tahun \\
\hline 4. & IT.4 & 35 tahun & DIII & $\begin{array}{l}\text { Case } \\
\text { manajer } \\
\text { VCT }\end{array}$ & 7 tahun \\
\hline
\end{tabular}


terselubung, artinya sikap yang positif atau negatif belum tentu mempunyai pengetahuan yang cukup tentang penyakit HIV/AIDS seperti yang diharapkan dan perilaku ini merupakan covert behavior yaitu pada pengetahuan, kesadaran dan sikap.

Sikap pada penyakit HIV/AIDS yang kurang baik kemungkinan disebabkan oleh beberapa faktor lain seperti tingkat pengetahuan apabila ibu rumah tangga tidak mengetahui tentang penyakit HIV/AIDS dapat berpengaruh terhadap perubahan sikap, kepahaman terhadap pengertian penyakit HIV/AIDS sangatlah berpengaruh terhadap sikap, ketidakpahaman mengenai pengertian, tanda dan gejala serta proses penularan HIV AIDS akan menimbulkan sikap kurang baik dalam sikap menerima keberadaan ODHA maupun penyakit HIV/AIDS itu sendiri.

\section{ANALISIS DATA KUALITATIF}

\section{a. Analisis Pengetahuan}

1) Pengetahuan tentang Penyakit Menular Seksual

Pengetahuan informan utama tentang PMS masih sangat terabatas. Sebagian besar informan mengatakan bahwa PMS merupakan penyakit yang disebabkan oleh hubungan seksual dengan berganti-ganti pasangan namun hanya 4 orang informan yang tidak mengetahui tanda gejala PMS. Seperti terangkum pada Kotak 1 sebagai berikut:

\section{Kotak 1}

Kulo mboten.. mboten ngertos nggih, opo sih penyakit hubungan po'? sing nular saking hubungan (IU.4S)

Semacam penyakit kulit iku, tapi kadang-kadang metu frustasine niku si bu sampe ngombe baygon, ngombe rinso. Penyakit kulit sing do nglotok. Ono siji meneh penyakit kelamin kuwi juga salah satune bu...(IU.3B)

Hahaha.. embuh mbak penyakit opo kuwi. Penyakit hubungan seks pog? Ora ngerti mba...(IU.7S)

Wah penyakit nopo niku mba? Kulo nggih mboten ngertos. Sak ngertiku penyakit kulit, penyakit sing disebabke sering gonta-ganti pasangan. Misale WTS opo wong lanang sing sering njajan biasane penyakite koyo kuwi mbak. (IU.8U)

\section{2) Pengetahuan tentang HIV/AIDS}

$$
\begin{aligned}
& \text { Semua informan utama } \\
& \text { menyatakan bahwa } \\
& \text { merupakan salah satu gejala } \\
& \text { penyakit HIV AIDS yang } \\
& \text { ditularkan lewat hubungan seks } \\
& \text { dengan berganti-ganti pasangan. } \\
& \text { Namun hanya } 3 \text { orang informan }
\end{aligned}
$$

utama yang mengetahui cara penularan HIV AIDS dengan jarum suntik (PENASUN) dan ibu hamil kepada anaknya serta hanya 2 informan utama yang mengetahui tanda gejala HIV AIDS yaitu batuk lama. 
Hal ini diungkap dalam

kotak 1 sebagai berikut :

hasil wawancara mendalam pada

Kotak 2

Nate mireng, ning mboten nate ningali mba. Sing nem-nem sing ngerti.

Penyakit saking suntik'an nopo, sing nularke niku jaler sing nakal-nakal nopo.

(IU.2T)

La juga akibat dari kebebasan seksual pog, penularane saking jarum suntik, seks bebas, ibu hamil pada anaknya. Gejalane yo batuk lama, nek panas dingin co'e ora. Sing risiko yo coe pecandu narkoba (IU.3B)

Nggih kados penyakit menular seks, ditularke lewat hubungan seks iku to mba, selaine hubungan biasane narkoba. Penyakit HIV niku dereng wonten obate sak ngertiku mba.(IU.5T)

“... ya penyakit nulare lewat seks sing gonta-ganti pasangan, gejalane awake gering, sering batuk-batuk, selain hubungan seks coe yo keluargane cok ketularan mba "(IU.8U).

Hasil penelitian

menyatakan bahwa hanya 1 orang informan utama yang mengetahui penyakit HIV/AIDS dari radio, seperti yang diungkap pada kotak 3 sebagai berikut :

\section{Kotak 3}

"Kalau saya denger dari radio sedikit sedikit, saya tahunya kalau penyakit hubungan kalau permulaan itu gatel gatel, tanda gejala selanjutnya saya tidak tahu.." (IU.4S).

Ada tidaknya sumber pengetahuan informan utama akan mempengaruhi pengetahuan informan utama tentang PMS maupun penyakit HIV/AIDS, karena pengetahuan diperoleh dari informasi baik lisan (misalnya dari petugas kesehatan) maupun tertulis (misalnya dari koran atau majalah) dan pengalaman seseorang. Pengetahuan juga diperoleh dari fakta (kenyataan) dengan melihat dan mendengar radio, televisi, dan sebagainya. Selain itu seseorang yang mempunyai sumber informasi lebih banyak akan mempunyai pengetahuan yang lebih luas (Soekanto, 2000).

Keterangan dari informan utama berbeda dengan keterangan dari informan triangulasi yang menyatakan bahwa sudah memberikan sosialisasi mengenai PMS ataupun HIV/AIDS kepada tokoh masyarakat. Pernyataan tersebut diungkap dalam hasil wawancara mendalam pada kotak 2 sebagai berikut :

\section{Kotak 4}

"Tapi kalau menurut kami kalau tentang HIV/AIDSnya sendiri itu pasti disinggunglah dalam pertemuan-pertemuan. Sosialisasi secara tidak formal atau tidak khusus untuk tema HIV/ADIS itu sudah disinggunglah" (IT.1)

"Saya kira ada masyarakat tahu akan tetapi masih banyak yang tidak tahu secara detail" (IT.2)

"Isi dari medianya yaa terkait tentang pengertian, cara penularannya cara pengobatannya dan lengkap semua" (IT.2) 
Kepedulian pemerintah dalam upaya pencegahan dan penanggulangan HIV dan AIDS di Indonesia ditunjukkan dengan dikeluarkannya Peraturan Presiden RI Nomor 75 Tahun 2006 Tentang Komisi Penanggulanag AIDS Nasional yang salah satu tugasnya mengadakan pengkoordinasian kegiatan penyuluhan, pencegahan, pemantauan, pengendalian, dan penaggulangan AIDS (Kholil, 2012).

Dalam penelitian Dermatoto (2010), pengetahuan tentang HIV AIDS yang baik serta dibarengi dengan sikap yang positif belum tentu seseorang dapat berperilaku baik terhadap hal tersebut. Ini disebabkan berbagai alasan seperti : belum adanya keberanian melakukan tes HIV, adanya perasaan takut mengetahui HIV positif dan keengganan melakukan tes HIV karena lebih menyukai untuk tidak mengetahui status terkait dalam masalah HIV/AIDS. Dalam hal ini untuk menurunkan angka penderita HIVAIDS, dibutuhkan peran serta orangtua, keluarga , lingkungan dan penyuluhanpenyuluhan pada semua lapisan masyarakat umumnya dan ibu hamil khususnya yang juga rentan terhadap HIV/AIDS.

Dalam penelitian Rosyidah (2009), pengetahuan, keyakinan dan faktor demografi serta faktor pendukung yang lain juga dapat mempengaruhi seseorang untuk bersikap. Dengan ini sudah dapat terbaca bahwa sikap yang baik dapat terbentuk dari pengetahuan yang baik.

Untuk mencegah penularan HIV/AIDS lebih luas lagi, Upaya yang dilakukan adalah membangun pengetahuan dan pemahaman yang memadai bagi anak muda dan wanita usia produktif akan kesehatan seksual dan reproduksi, di mana HIV termasuk di dalamnya.

3) Pengetahuan tentang klinik VCT di Kota Pekalongan

Semua informan mengatakan belum mengetahui adanya klinik VCT di Kota Pekalongan, namun 1 informan mengatakan biasanya di rumah sakit ada pelayanan VCT. dinyatakan diungkap dalam hasil wawancara mendalam pada kotak 5 sebagai berikut :

Kotak 5

"Rumah sakit biasane wonten. Klinik'e selain RS ndak tau mba" (IU.6B) 


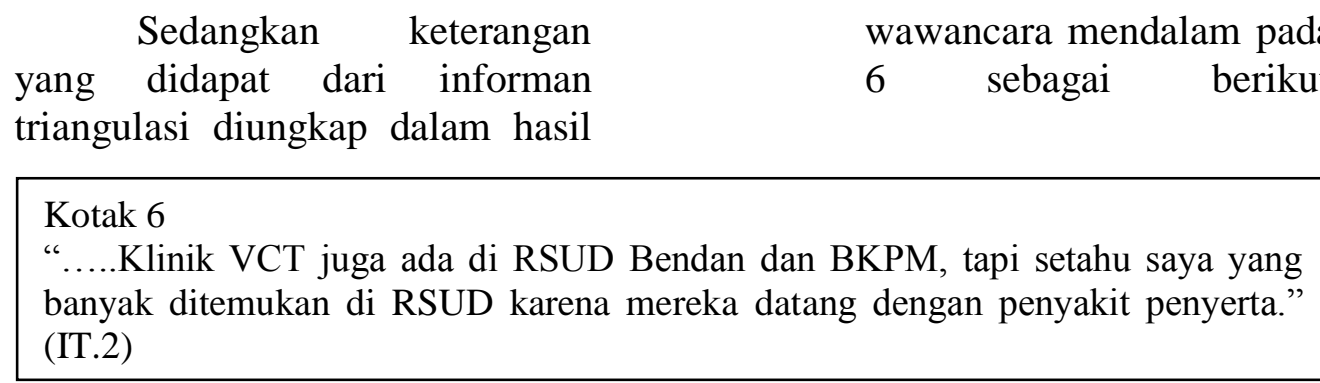

Hal ini ditunjang dengan

keterangan yang didapat dari informan triangulasi BKPM yang

diungkap dalam hasil wawancara mendalam pada kotak 7 sebagai berikut

Kotak 7

“.....Klinik VCT yang ada di BKPM ini biasanya banyak pasien dari lapas dan mungkin pasiennya lebih banyak di RSUD Bendan karena dari BKPM sendiri ruiukannva ke RSUD Bendan..” (IT.4)

Klinik VCT diperlukan karena merupakan pintu masuk untuk menuju keseluruh layanan HIV/AIDS, dapat memberikan keuntungan bagi klien dengan hasil tes positif maupun negatif dengan fokus pemberian dukungan terapi ARV (Anti Retroviral), dapat membantu mengurangi stigma di masyarakat, serta dapat memudahkan akses ke berbagai layanan kesehatan maupun layanan psikososial yang dibutuhkan klien (Murtiastutik, 2008).

4) Pengetahuan Adanya Organisasi dibidang pencegahan penularan HIV/AIDS

Semua informan utama menyatakan tidak tahu organisasi yang bergerak dibidang pencegahan HIV/AIDS di Kota Pekalongan. Pernyataan tersebut diungkap dalam hasil wawancara mendalam pada kotak 8 sebagai berikut

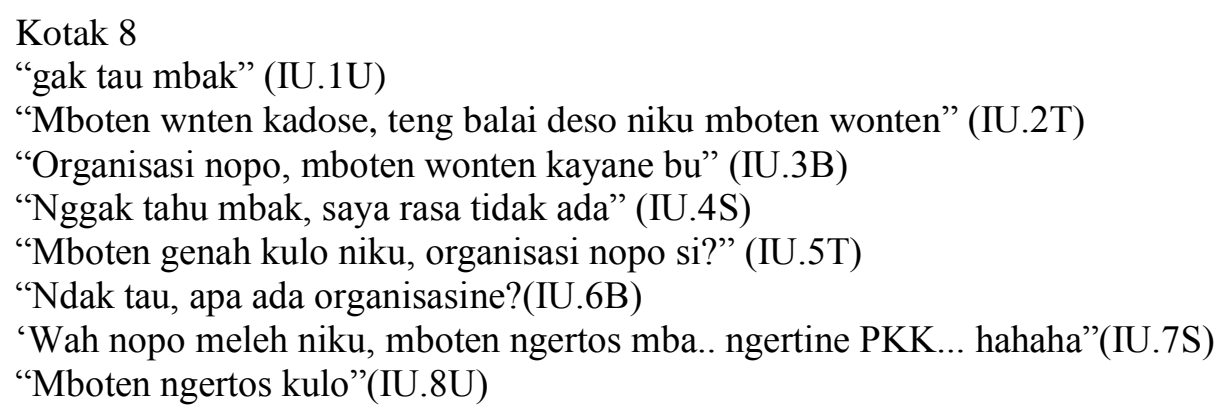

Pernyataan dari informan utama hampir sama dengan keterangan dari informan triangulasi, namun informan triangulasi menyatakan terdapat komite penanggulangan HIV/AIDS (KPA) yang berada di Dinas Kesehatan Kota 
Pekalongan. Pernyataan tersebut diungkap dalam hasil wawancara mendalam pada kotak 9 sebagai berikut

\section{Kotak 9}

“....di dinas sendiri sudah ada Komite Penanggulangan HIV AIDS ...”(IT.2)

$\begin{array}{lrrr}\text { Penyataan dari informan } & \text { Komite Penanggulangan HIV I } \\ \text { triangulasi ditunjang } \text { dengan } & \text { AIDS (KPA) pada kotak } 10 \\ \text { pernyataan dari Case Manager } & \text { sebagai } & \text { berikut: }\end{array}$

klinik VCT yang menyatakan ada

Kotak 10

“....lewat KPA dulu kemudian turun Perda dan harusnya kepala daerah harus

konsentrasi terhadap pengananan HIV AIDS ..." (IT.4)

5) Gambaran penderita HIV/AIDS

Enam orang informan
utama mengatakan tidak

mengetahui gambaran penderita

HIV/AIDS karena belum pernah

melihatnya, dan hanya 2 informan mengatakan bahwa penderita HIV AIDS berbadan kurus dan sering batuk. Pernyataan tersebut diungkap dalam hasil wawancara mendalam pada kotak 11 sebagai berikut

Kotak 11

"Lemes, awake alit niku si ..." (IU.2T)

"La kuwi kayane wonge niku gering, sering batuk-batuk.. ceking niku si...." (IU.8U)

\begin{tabular}{|c|c|}
\hline triangulasi & berkomunikasi \\
\hline menyatakan bahwa pernah & langsung \\
\hline membawa ODHA pada saat & tersebut diungka \\
\hline memberikan sosialisasi kepada & dalam hasil wawancara menda \\
\hline masyarakat mengenai HIV/AIDS & pada kotak 12 sebagai berikut \\
\hline
\end{tabular}

Kotak 12

“...Dulu pernah saya ngasih tu sama dr. Muhis dari Semarang kita bawa testimoni orangnya juga sehingga peserta bisa komunikasi langsung dengan penderita..." (IT.1)

“....bahkan sampai mendatangkan ODHA" (IT.2)

Faktor pekerjaan informan utama juga mempengaruhi pengetahuan informan dimana informan utama bekerja dari pagi sampai sore sehingga tidak bisa mengikuti perkumpulanperkumpulan di lingkungannya yang dimungkinkan ada sosialisasi mengenai HIV/AIDS maupun berbagai macam hal yang lain.

\section{b. Analisis Sikap}

1) Sikap bila bertemu ODHA 
Semua informan menyatakan tidak akan mendekati penderita HIV/AIDS tetapi masih bersedia untuk bersalaman.
Pernyataan tersebut diungkap dalam hasil wawancara mendalam pada kotak 13 sebagai berikut:

Kotak 13

“Kalau nyapa ya saya menjawab tetapi tidak saya dekati biar tidak tertular, kalau hanya bersalaman sebentar yaa tidak apa apa, tidak memperlihatkan kalau saya menghindari, kalau menghindar itu kasihan sama orangnya yang sakit, kalau diajak berbincang agak lama beralasan untuk cepat pergi. (IU.1,2,3,4,5,6,7,8)

Rasa takut dan khawatir masyarakat akan menimbulkan hukuman sosial terhadap penderita ODHA. Hukuman sosial berupa stigmasi dan diskriminasi oleh masyarakat di berbagai belahan dunia terhadap pengidap AIDS terdapat dalam berbagai cara, antara lain tindakan-tindakan pengasingan, penolakan, diskriminasi, dan penghindaran atas orang yang diduga terinfeksi HIV diwajibkannya uji coba HIV tanpa mendapat persetujuan terlebih dahulu atau perlindungan kerahasiaannya dan penerapan karantina terhadap orang-orang yang terinfeksi HIV. Kekerasan atau ketakutan atas kekerasan, telah mencegah banyak orang untuk melakukan tes HIV, memeriksa bagaimana hasil tes mereka, atau berusaha untuk memperoleh perawatan sehingga mungkin mengubah suatu sakit kronis yang dapat dikendalikan menjadi hukuman mati dan menjadikan meluasnya penyebaran HIV.
Dukungan

sebaya merupakan dukungan sesama yang dilakukan oleh Odha atau Ohidha kepada Odha dan Ohidha lainnya, terutama Odha yang baru mengetahui status HIV. Dukungan sebaya berfokus pada peningkatan mutu hidup Odha khususnya dalam peningkatan percaya diri; peningkatan pengetahuan HIV/AIDS; akses dukungan, pengobatan dan perawatan; pencegahan positif dengan melakukan perubahan perilaku; dan kegiatan produktif. Keberadaan ODHA harus diperhatikan oleh instansi kabupaten/Kota.

Hal ini sejalan dengan pernyataan informan triangulasi Kabid BPMP2AKB, menyatakan bahwa jika BPMP2AKB menemukan ODHA baru akan menginformasikan keberadaan ODHA baru tersebut kepada Dinas Kesehatan. Pernyataan tersebut diungkap dalam hasil wawancara mendalam pada kotak 14 sebagai berikut:

Kotak 14

“...Kalau ditempat saya tidak ada tupoksi itu. Walau tidak ada tupoksi, kami selalu merapat ke Lapas ya, karena di lapas itu banyak penderitanya disana, tapi itu tidak dianggap sebagai data nya Kota Pekalongan karena mereka bukan asli penduduk Kota Pekalongan dan dinkes menganggapnya itu wilayahnya Kemenham. Tapi menurut kami karena itu berada di Kota Pekalongan itu juga sangat sensitif karena mereka bisa menikah dengan orang sini setelah keluar. Kita masuknya ke wilayah sana karena kita bekerja sama dengan lapas atau rutan mengadvokasi kalau disana ada ODHA, jadi kita bekerja sama dengan lapas itu kalau mereka punya data dan terus kemudian kita menginformasikannya ke Dinkes. Menurut kami harusnya dinkes yang proaktif untuk mengadvokasi ODHA disana karena tahu data. Kalau kami tahu data itu dari lapas jadi ya kerjakan yang di lapas. (IT.1) 
Sama seperti hasil wawancara dengan Kabid P2-PL (Dinkes) yang menyatakan bahwa jika menemukan ODHA maka akan dilakukan pendampingan terhadap
ODHA dan keluarganya. Pernyataan tersebut diungkap dalam hasil wawancara mendalam pada kotak 15 sebagai berikut

Kotak 15:

“...Bila menemukan ODHA dari Dinas sendiri melakukan pendampingan terhadap ODHA, pendampingan dilakukan dirumah termasuk pada istrinya pada anaknya biasanya yang disampaikan keistrinya yaaa pelan pelan dari penyebabnya dari mana, mengidap penyakit itu setelah atau sebelum berkeluarga, dengan perilaku itu kemudian diberikan konseling dan pengobatan dengan melakukan pendekatan terhadap keluarga (IT.1)

2) Sikap Pencegahan Penularan HIV/AIDS

5 informan utama menyatakan harus berhati-hati dan tidak berdekatan dengan penderita HIV/AIDS dan 3 informan menyatakan HIV/AIDS bisa menular melalui keringat atau kontak kulit. Pernyataan tersebut diungkap dalam hasil wawancara mendalam pada kotak 16 sebagai berikut:

Kotak 16 :

“...Tidak dekat dekat dengan yang menderita sakit HIV AIDS, tidak ngobrol lama dengan ODHA “(IU. 2,4)

“..HIV kui perasaan ndak menular si, yo ora ngerti kabeh o.. nek kontak ngobrol yo orak menular.. dalam artian nek kojahan mbek kojahan yo orak menular, kulit mbek kulit yo ora menular..." (IU.1-3)

“...Ngati-ngati bae, ora pedek-pedek karo wong e..." (IU.5T)

“...Nek biso aku ora sebelahan karo wong sing duwe penyakit HIV/AIDS..." (IU.7S)

\begin{tabular}{|c|c|}
\hline  & $\begin{array}{lrr}\text { masyarakat kedepannya. } & \text { Sikap } \\
\text { lapang dada, toleransi dan } & \text { da } \\
\text { kepedulian serta kerjasama } \\
\text { masyarakat diharapakan } & \text { mampu } \\
\text { membantu } & \text { menekan } & \text { dan } \\
\text { meminimalkan } & \text { bahkan }\end{array}$ \\
\hline
\end{tabular}


menyelesaikan permasalahan penyebaran HIV/AIDS.

Sedangkan menurut hasil wawancara dengan informan triangulasi BPMP2AKB jika menemukan IRT yang ODHA
/OHIDA BPMP2AKB tidak langsung mengadvokasi ODHA hanya pada upaya preventif. Pernyataan tersebut diungkap dalam hasil wawancara mendalam pada kotak 17 sebagai berikut:

Kotak 17 :

“...data itu (IRT yang merupakan ODHA) dipegang dinkes by name by address da itu dianggap tidak boleh keluar. Tupoksinya disana. Wilayah kami di Bappermas tidak langsung mengadvokasi penderita, dari kami upayanya ke preventif/pencegahannya. Datanya yang pegang kan dinkes, saya tidak tahu model penanganannya kalau ada kasus. (IT.1)

Sedangkan menurut hasil wawancara dengan Kabid P2-PL (Dinas Kesehatan), jika menemukan IRT yang ODHA /OHIDA penanganannya hanya sebatas jika IRT yang merupakan
ODHA diberikan obat ARV dan penyuluhan. Pernyataan tersebut diungkap dalam hasil wawancara mendalam pada kotak 18 sebagai berikut:

Kotak 18 :

“...yaa ini Intinya mereka disuruh minum obat karena minimal bisa memperpanjang usia walaupun bukan menyembuhkan, penyuluhan jelas pada seluruh keluarganya tidak hanya pada IRT saja, biasanya rata-rata IRT yang kena suaminya sudah meninggal dan diharapkan tidak hamil lagi (IT.2)

\section{Hasil wawancara dengan \\ Case Manager Klinik VCT} menyatakan bahwa pasien yang datang ke klinik akan diberikan konseling, dilanjutkan dengan tes HIV, lalu dirujuk ke RSUD Bendan untuk mendapatkan penanganan lebih lanjut. Pernyataan tersebut diungkap dalam hasil wawancara mendalam pada kotak 19 sebagai berikut:

Kotak 19:

“...Bila ada yang terinfeksi maka akan diberikan konseling, diperiksa kemudian pasca periksa dirujuk ke RSUD Bendan untuk mendapatkan pengobatan lebih lanjut..." (IT.4)

\begin{tabular}{|c|c|}
\hline Diskriminasi & 3) Sikap terhadap tetangga dengan \\
\hline masyarakat & HIV/AIDS \\
\hline HIV/AIDS & menyatakan \\
\hline menambah beban secara emosional & menghindari tapi tidak terlihat. 6 \\
\hline ODHA & menyatakan \\
\hline Ketidaktahuan & menyapa \\
\hline mengenai HIV/AIDS lah yang & beralaman tetapi tidak terlalu lama \\
\hline mempengaruhi sikap masyarakat & dan berbincang \\
\hline kepada ODHA. & Pernyataan tersebut diungkap \\
\hline
\end{tabular}


Kotak 20 :

“...Ngindari tapi ampun ketoro, wong nular kan mbak ya “ (IU.2)

“...Yo brusaha ngadohi, aku wedi ketularan. Jenenge penyakit ora ono sing ngerti, menungso mung biso usaha" (IU.7S)

Menjaga hubungan baik dengan tetangga merupakan hal dasar dalam hidup ditengah-tengah masyarakat. Bertegur sapa dengan tetangga mampu mempererat hubungan kekeluargaan dengan tetangga. Apapun kondisi sosial, ekonomi dan kesehatan tetangga bukanlah suatu alasan yang dibenarkan untuk memutus tali silaturahmi, bahkan berlaku pada tetangga dengan HIV/AIDS.
4) Sikap pada nggota keluarga yang merupakan ODHA

Semua informan akan memisah alat mandi, alat makan, mencuci pakaian dan tidak tidur atau bermain bersama penderita HIV/AIDS. Pernyataan tersebut diungkap dalam hasil wawancara mendalam pada kotak 21 sebagai berikut

\section{Kotak 21 :}

“...Yo memberikan support dorongan, nek wis genah positif yo sukuri jalani hidup ini ambl positife bae. Nek kaakan serumah yo, tapi nek ora ono obate kan buk..nek alat mandi yo karo anak-anak wis tak pisah dewe-dewe, alat mandi, anduk, nek nyuci pakaian yo tetep tak pisah o bu nek apan genah ngerti wis penyakit positif yo jelas alat makane. (IU.1, 2,3,4,5,6,7,8)

$\begin{array}{ll}\text { Menurut hasil wawancara } & \text { Kota Pekalongan adalah jika di } \\ \text { dengan informan triangulasi } & \text { lapas modelnya terapi kelompok. } \\ \text { BPMP2AKB dalam kaitanannya } & \text { Pernyataan tersebut diungkap } \\ \text { Pelayanan dan terapi yang } & \text { dalam hasil wawancara mendalam } \\ \text { disediakan bagi ODHA di wilayah } & \text { pada kotak 22 sebagai berikut: }\end{array}$

Kotak 22 :

“...modelnya di lapas itu terapi kelompok, jadi tahu. Tapi kan laki-laki semua lapas kita itu. Jadi tahu bahwa resiko para istrinya sudah kena juga. Di Pekalongan kan kita gak tahu ada model, jadi penanganannya itu di dinkes, jadi tupoksinya disana. Jadi kita mlipit-mlipit pada pencegahan (IT.1)

Sedangkan menurut hasil wawancara dengan Kabid P2-PL (Dinas Kesehatan), dalam kaitanannya Pelayanan dan terapi yang disediakan bagi ODHA di wilayah Kota Pekalongan diungkap dalam hasil wawancara mendalam pada kotak 23 sebagai berikut:

Kotak 23 :

“...pelayanan dengan konsultasi yang dilakukan oleh konselor dari Dinas kesehatan dan pendampingan untuk minum obat ARV yang dilakukan dirumah (IT.2) 
ODHA membutuhkan dukungan sosial, ekonomi, emosional dan spiritual yang berkelanjutan. Keluarga merekapun membutuhkan pelatihan, bimbingan dan dukungan. Sejak dinyatakan terinfeksi HIV penderita mengalami stres, dikarenakan tingginya tekanan psikososial yang mereka terima baik dari keluarga maupun masyarakat. Oleh karena itu dukungan sosial terutama dari keluarga penting artinya, dan sangat menentukan perkembangan penyakit yang berdampak pada ketiga aspek dalam respon sosial (emosional) pasien HIV-AIDS.

Sikap yang ditunjukkan oleh informan triangulasi kabid BPMP2AKB, tentang kebijakan BPMP2AKB Kota Pekalongan dalam pemanfaatan klinik VCT di Kota Pekalongan menyatakan bahwa kasus HIV AIDS yang ditemukan maka akan dirujuk ke LPPAR. Pernyataan tersebut diungkap dalam hasil wawancara mendalam pada kotak 24 sebagai berikut:

Kotak 24 :

"...menurut saya gak terlalu. Menurut saya yang disana itu, di Panjang. Jadi kebetulan kalau kasus ada yang masuk di LPPAR yang kasus kaitannya dengan homoseks atau apa itu pasti saya rujuk kesana untuk pemeriksaan kan. Jadi untuk ketuntasannya. Kalau yang Bendan saya denger malah gak terlalu ini, terlalu terbuka kayaknya gak banyak sih. Kalau yang sana itu (di Panjang) memang iya, itu milik pemerintah kota (IT.1)

\section{Sedangkan sikap dari Kabid}

PP-PL (Dinas Kesehatan), tentang kebijakan BPMP2AKB Kota Pekalongan dalam pemanfaatan klinik VCT di Kota Pekalongan menyatakan bahwa klinik VCT sudah ada akan tetapi pemanfaatannya belum maksimal karena ODHA ditemukan berdasarkan penyakit HIV AIDS melainkan penyakit penyertanya. Pernyataan tersebut diungkap dalam hasil wawancara mendalam pada kotak 25 sebagai berikut:

Kotak 25 :

“...HIV terkait tentang TBC selama ini sudah ada 2 klinik VCT yaitu di Balai paru di daerah panjang dan RSUD Bendan, Paling banyak kasus ditemukan adalah di RSUD Bendan karena mereka datang bukan berdasarkan penyakit HIV AIDS melainkan penyakit penyertanya (IT.2)

Sedangkan menurut Informan triangulasi Kabid Sosial (Dinsos) menyatakan bahwa keberadaan organisasi sosial yang bergerak di bidang pencegahan
HIV AIDS belum ada. Pernyataan tersebut diungkap dalam hasil wawancara mendalam pada kotak 26 sebagai berikut:

Kotak 26 :

“...Belum ada organisasi sosialyang bergerak di bidang pencegahan HIV AIDS karena sudah ditangani oleh Dinas Kesehatan (IT.3) 
Menurut informan triangulasi Kabid Sosial (Dinsos) tidak ada kebijakan khusus untuk WRSE atau pekerja seks yang telah menjadi ODHA dari Dinas Sosial. Pernyataan tersebut diungkap dalam hasil wawancara mendalam pada kotak 27 sebagai berikut:

Kotak 27 :

“...Tidak ada karena ranahnya kalau terkait tentang HIV AIDS adalah DinKes, yang dibina dari Dinsos sudah mandiri yaitu dibina untuk cari nafkah sendiri (IT.3)

Pernyataan-pernyataan

sikap WRSE diatas sebagian besar menunjukkan menghindari ODHA karena takut tertular, bahkan kepada anggota keluarga sendiri. Hal ini sesuai dengan teori yang dikemukakan oleh Pertiwi (2009) bahwa sikap negatif yang dilakukan masyarakat terhadap ODHA (Orang dengan HIV/AIDS) ini disebabkan oleh ketidaktahuan masyarakat dengan jelas cara-cara penularan HIV, masyarakat hanya mengetahui HIV/AIDS itu merupakan sebatas penyakit menular, penderitanya berbahaya, dan fakta AIDS sebagai penyakit mematikan. Dibutuhkan informasi untuk merubah sikap masyarakat terhadap ODHA sehingga tidak lagi mendiskriminasikan ODHA dalam kehidupan bermasyarakat.

\section{SIMPULAN}

1. Pengetahuan WRSE tentang PMS, HIV/AIDS serta gambaran penyakit HIV AIDS masih sangat terabatas.

2. Terbatasnya pengetahuan masyarakat salah satunya disebabkan oleh kurangnya sosialisasi.

3. Sikap negatif yang dilakukan masyarakat terhadap ODHA (Orang dengan HIV/AIDS) ini disebabkan oleh ketidaktahuan masyarakat dengan jelas cara-cara penularan HIV.

\section{SARAN}

1. Bagi Instansi terkait

a. Mengedepankan koordinasi antar instansi dalam memberikan sosialisasi kepada masyarakat, terutama sosialisasi yang berhubungan dengan pencegahan penularan penyakit

b. Memberikan sosialisasi tidak hanya kepada pemuda maupun tokoh masyarakat agar informasi yang diberikan bisa tersebar lebih luas, menyertakan pasangan suami istri dalam sosialisasi

c. Menambah jenis media informasi yang digunakan untuk sosialisasi HIV/AIDS dan isi informasi yang disampaikan kepada masyarakat untuk lebih detail mengingat mudahnya ibu rumah tangga tertular virus HIV

d. Membentuk organisasi masyarakat yang bergerak di bidang pencegahan penularan HIV/AIDS untuk membantu menyebarluaskan informasi mengenai HIV/AIDS kepada masyaraka

2. Bagi Penelitian Lanjutan

a. Menambah variabel penelitian yang dikaji mengenai upaya pencegahan penularan HIV/AIDS pada ibu rumah tangga (WRSE)

b. Memperkecil bias wawancara penelitian dengan cara peneliti mengumpulkan informasi berbeda 
dengan peneliti sebelumnya yang melakukan interpretasi hasil test

3. Bagi Pemangku Kebijakan

Membentuk organisasi yang bergerak di bidang perlindungan dan pencegahan penularan HIV/AIDS
4. Bagi Instansi Pendidikan

Membentuk organisasi/lembaga kemahasiswaan yang bergerak di bidang perlindungan pencegahan penularan HIV/AIDS didalam maupun antar instansi pendidikan. 